\title{
Bevezető gondolatok
}

\author{
SKODÁNÉ FÖLDES Rita* \\ Pannon Egyetem, Természettudományi Központ, Szerves Szintézis és Katalizis Kutatócsoport, \\ Egyetem u. 10. 8200 Veszprém
}

\begin{abstract}
A Pannon Egyetem Mérnöki Karán a több mint hét évtizedre visszatekintő vegyészmérnök- és az 1994 óta folyó vegyészképzésnek megfelelően a kémiai és vegyipari tárgyú kutatások adják a Kar K+F tevékenységének jelentős részét.
\end{abstract}

A hagyományosan müvelt tématerületek, a molekulaspektroszkópia, folyadékkromatográfia, fotokémia, fémorganikus katalízis szinte a kezdetektől jelen voltak és vannak a kutatási palettán. A kollégák érdeklődése ezeken a területeken belül olyan témák felé fordult, amelyek elősegítik a modern kémiai technológiai megoldások kifejlesztését.

Az agyagásványok változatos szerkezetük és előnyös felületi tulajdonságaik következtében ideális katalizátorok vagy katalizátor-hordozók lehetnek. Röntgendiffrakciós, termoanalitikai és molekulaspektroszkópiás jellemzésük alapvető információkat szolgáltat a katalitikus tulajdonságok feltérképezéséhez, kémiai módosításuk pedig kedvezö szerkezeti változásokat idéz elő. A katalízis szempontjából is lényeges a nanopórusos zeolitok és agyagásványok pórusaiban végbemenő adszorpciós és anyagtranszport folyamatok ismerete, melyhez jelentős segítséget nyújt a számítógépes szimuláció.

A fém-porfirin komplexek jelenlétében lejátszódó homogén, illetve a $\mathrm{TiO}_{2}$-alapú heterogén fotokatalitikus reakciók tanulmányozása víztisztításra és napenergia-hasznosításra alkalmazható vagy - megfelelően megválasztott kiindulási vegyületek esetén - potenciálisan bioaktív termékekhez vezető rendszerek kifejlesztését eredményezi. Biológiailag aktív molekulák királis építőelemeinek szintézise hatékonyan valósítható meg könnyen hangolható, moduláris felépítésü ligandumokat tartalmazó fémkomplexek segítségével végrehajtott enantioszelektív katalitikus reakciókkal. Az ionfolyadékok mint oldószerek és/vagy katalizátorok alkalmazása módot ad a katalizátor-oldószerelegy vagy - hordozóra rögzített ionfolyadékok esetén - a katalizátor visszaforgatására, ezáltal a káros hulladékok mennyiségének csökkentésére.

Számos kutatás irányul a biológiai rendszerek jobb megértésére és kémiai alkalmazási lehetőségeik feltérképezésére. A fémorganikus enzimmodellek tanulmányozása egyrészt támpontot ad az enzimek müködési mechanizmusának jobb megértéséhez, másrészt lehetőséget nyújt új, nagy hatásfokú katalitikus rendszerek kifejlesztéséhez. A hulladékkezelésben, megújuló alapú energiatermelésben alkalmazható bioelektrokémiai rendszerek hatékonyságának növelésére irányulnak az új membrántípusok kidolgozására és tesztelésére irányuló kutatások. A számítógépes szimuláció hasznos eszköznek bizonyult ioncsatornák müködésének leírására. A szilikátipari kutatások a hulladékok hasznosításától a bioaktív kerámiák előállításáig a tématerületek széles spektrumát fogják át.

A Magyar Kémiai Folyóirat e számában megjelenő közlemények, melyek az alapkutatással foglalkozó csoportok munkatársainak tollából születtek, az elmúlt 5-10 év eredményeit foglalják össze.

* Tel.: +36 88624 719; e-mail: skodane@almos.uni-pannon.hu 